\title{
Renal cell carcinoma: a systematic review and meta-analysis on expression of androgen receptor
}

\author{
Hossein Abdi ${ }^{1}$, Hamid Reza Mozaffari² ${ }^{2}$ Mehrdad Payandeh ${ }^{3}$, Edris Sadeghi ${ }^{4}, *$
}

${ }^{1}$ Department of Urology, Imam Reza Hospital, Kermanshah University of Medical Sciences, Kermanshah, Iran

${ }^{2}$ Department of Oral and Maxillofacial Medicine, School of Dentistry, Kermanshah University of Medical Sciences, Kermanshah, Iran

${ }^{3}$ Department of bone marrow transplantation, Imam Reza Hospital, Kermanshah University of Medical Sciences, Kermanshah, Iran

${ }^{4}$ Department of Nursing, School of Nursing and Midwifery, Kermanshah University of Medical Sciences,

Kermanshah, Iran

\section{Correspondence}

Edris Sadeghi, Department of Nursing, School of Nursing and Midwifery, Kermanshah University of Medical Sciences, Kermanshah, Iran

Email: Sadeghi_mkn@yahoo.com History

- Received: 16 October 2018

- Accepted: 17 November 2018

- Published: 28 November 2018

DOI :

https://doi.org/10.15419/bmrat.v5i11.500

\section{Check for updates}

Copyright

( $)$ Biomedpress. This is an openaccess article distributed under the terms of the Creative Commons Attribution 4.0 International license.

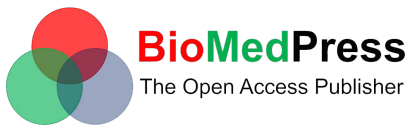

\begin{abstract}
Background: Chromosome $\mathrm{Xq11-12}$ is the place that the androgen receptor (AR) sequence appears. Herein, the prevalence of this biomarker and its relation with pT stage and tumor grade was reported. Methods: Four online sites (PubMed, Scopus, Web of Science, and Cochrane Library) have been searched up to Sep 2018 systematically. Meta-Analysis software version 2.0 (CMA 2.0) and STATA 14.0 statistical software were utilized. Publication bias did not exist. Results: From the initial 1141 articles identified from the systematically searches. At last, nine of them remained for analysis. The meta-analysis included 1447 patients that 345 of them had AR expression. AR expression significantly correlated with low tumor grade and low tumor pT stage. Conclusion: AR expression was $28.2 \%$, and it had the relationship with tumor low grade and low pT stage. Additional studies required to figure out the role of it on RCC patients.

Key words: AR, Grade, pT stage, RCC
\end{abstract}

\section{INTRODUCTION}

Renal cell carcinoma (RCC) is the foremost different urological malignancy among adults ${ }^{1}$. The most prevalent form of malignancy RCC is clear cell RCC (ccRCC) and represents over $90 \%$ of malignant kidney tumors ${ }^{2}$. The androgen receptor (AR) sequence is found at chromosome Xq11-12 and includes of eight exons ${ }^{3}$. Prevalence of the AR is appeared in several parts of the body, principally in sexual parts of men. Also, it was reported in breast, bladder, liver, gastrointestinal $^{4}$. High AR expression is potential prognosis factor in bladder cancer ${ }^{5}$, and it created longer life in patients with serous carcinoma of the ovary ${ }^{6}$, an agent for progressive the squamous cell carcinoma of head and neck ${ }^{7,8}$. We tend to are responsive to only rare studies evaluating AR immunohistochemical staining in $\mathrm{RCC}^{9-11}$. Though the targeted therapy creates an effective route for advanced RCC patients ${ }^{12}$, the relationship between AR expression and RCC progression stay uncertain until now ${ }^{13}$. This meta-analysis reports the expression of $\mathrm{AR}$ and its relation with some pathological factors in RCC.

\section{METHODS}

\section{Search Strategy}

PubMed, Scopus, Web of science, and Cochran library included in this study. Search terms included systematically up to September 2018 were "androgen receptor", "AR”, "kidney”, "renal cell carcinoma”, "cancer", "carcinoma", and "tumor. The studies were searched for the assessment of expression of the AR in RCC patients in English abstract.

\section{Inclusion and Exclusion Criteria}

\section{Inclusion criteria:}

1) Cohort studies

2) Human studies

\section{Exclusion criteria:}

1) Case-control, case report, and review studies; conference paper and letter to editor

2) The study with incomplete data

\section{Data extraction}

First author, year of publication, nation, RCC samples, expression, grade, $\mathrm{pT}$ stage, number of males, and the mean age were extracted. We could not have analysis on types of survival as a result of the studies didn't have the same data.

\section{Statistical analysis}

Comprehensive Meta-Analysis software version 2.0 (CMA 2.0) and STATA 14.0 statistical software (StataCorp LP, College Station, TX, USA) were used for random-effect analysis. P-value $(2$-sided $)<0.05$ is significant. 


\section{CMA 2.0}

The event rate (ER) with $95 \%$ confidence interval (95\% CI) was calculated for estimation of the expression of AR mutations in RCC patients. Begg's and Egger's tests were calculated for bias.

\section{STATA 14.0}

$\mathrm{P}<0.1$ is significant for heterogeneity. Heterogeneity is assessed by the $\mathrm{Q}$ and $\mathrm{I} 2$ statistics.

\section{RESULTS}

After primary searches, 1141 articles identified. Twenty one studies remained after we excluded the non-relevant studies. Then, twelve studies were removed based on reasons (five conference papers, three reviews, two articles without full text, one letter to editor, and one database). At last, nine of them remained for analysis (Figure 1).

From nine studies ${ }^{9-11,14-19}$, two studies ${ }^{14,17}$ were Germany, two studies ${ }^{15,19}$ were USA and others were from Austria ${ }^{9}$, Korea ${ }^{10}$, China ${ }^{11}$, Italy ${ }^{16}$ and Japan ${ }^{18}$. From 1447 patients $^{9-11,14-19}$, 345 AR expression exist. One hundred seventy-one cases in four studies ${ }^{9-11,18}$ of meta-analysis study were male, and 59 cases were female (sum=202). Mean age (min-max) in two studies was 60.06 (29-82). Three studies ${ }^{9,11,14,18}$ on pT stage in 132 patients with expression AR showed 51 cases pT stage 1, 20 cases pT stage 2, 41 cases pT stage 3. And also, 160 low grade versus 42 high-grade cases exist in four studies $^{9-11,18}$ (Table 1).

\section{AR Expression}

The prevalence of AR expression in RCC patients has been reported in Figure 2 by the ER. The pooled ER of the studies was $28.2 \% \quad(95 \%$ $\mathrm{CI}=16.3 \%-44.3 \% ; \quad \mathrm{P}=0.009)$. The Begg's and Egger's tests didn't show publication bias $(\mathrm{P}=0.53$ and $\mathrm{P}=0.75$, respectively)(Figure 3 ).

\section{AR expression and tumor grade}

Among three studies (502 cases), heterogeneity was existed $\left(\mathrm{I}^{2}=85.80 \%, \mathrm{p}=0.0\right)$ in a fixed-effects model. Correlation between AR expression and low grade was positive (OR, 1.98; 95\% CI, 1.44-2.71; $\mathrm{P}<0.01$ ) (Figure 4).

\section{AR and $p T$ stage}

Among three studies (848 cases), heterogeneity was not existed $\left(\mathrm{I}^{2}=4.3 \%, \mathrm{p}=0.353\right)$. Correlation between AR expression and low pT-stage was positive (OR, 4.04; 95\% CI, (3.10-5.26); $\mathrm{P}<0.01$ ) (Figure 5).

\section{DISCUSSION}

Radiotherapy, chemotherapy, and immunotherapy used for treat metastatic RCC patients ${ }^{12}$. But, a lot of controversial for treatment of this malignancy are existed until now ${ }^{13,17}$. Moreover, AR expression has been related to chemo-responsiveness ${ }^{20}$. Exaggerated AR expression was related to attenuate responsiveness and exaggerated migration of tumor cells $^{21}$. The clear cell RCC resists chemotherapy and radiation with a restricted therapeutic period of the anti-angiogenesis targeted therapy (6-15 months) ${ }^{22}$. Clinical researchers have disclosed that some patients reply to endocrine therapy objectively or subjectively ${ }^{23,24}$. AR can help to the pathobiology of breast malignancy ${ }^{25}$, and maybe inhibition of androgen sign had a therapeutic role in it ${ }^{26}$. Firstly, AR was observed in cancerous renal tissues and then appears in other urinary organs like prostate and then breast cancer ${ }^{27}$. Nakano et al., who noted that patients with RCC showing immunoreactivity for one or a lot of hormone receptors (ER, PR and/or AR) had a considerably higher survival rate ${ }^{18}$. A cohort found that AR expression in clear cell RCC was prognostic which high expression ${ }^{28}$. Cut off for express AR reported from $12.9 \%$ to $100 \%^{29-31}$. AR expression found in non-invasive urothelial malignancies as compared to invasive urothelial malignance ${ }^{32,33}$.

Consequently, AR immunoreactivity was related to renowned favorable prognostic factors, like tiny tumor size, low pT stage (more than $30 \%$ in pT1a tumors) in addition as low histological grade ${ }^{34}$. The AR-positive rate ranged from $16.3 \%-44.3 \%$ in RCC tissues in this study. Noh et al., ${ }^{10}$ and Concolino et al., ${ }^{16}$ showed the level of AR-positive is higher than our meta-analysis. In other hands Langne et al., ${ }^{9}$ and Klotzl et al., ${ }^{17}$ demonstrated that the AR-positive is lower than in this study among RCC patients. Nine studies (1,447 cases) surveyed for AR expression in RCC patients in the meta-analysis and also expressed relationship tumor grades and $\mathrm{pT}$ stages with it. Zhu et al., ${ }^{11}$ incontestable that AR expression rate was negatively accompanied pT stage and Fuhrman's grade in RCC patients. Also, this relationship was indicated by Foersch et al., ${ }^{14}$ and Langner et al. ${ }^{9}$, Zhu et al., ${ }^{11}$ reported prevalence of $\mathrm{AR}$ had a negative relationship with pT stage and grade in RCC patients. Foersch et al., ${ }^{14}$ and Langner et al., ${ }^{9}$ reported the results opposite of him. Noh et al., ${ }^{10}$ said AR expression related with the histological nuclear grade $(\mathrm{p}<0.027)$ and TNM stage $(\mathrm{p}<0.002)$. The meta-analysis showed AR expression correlated with low grade and $\mathrm{pT}$ stage positively. 


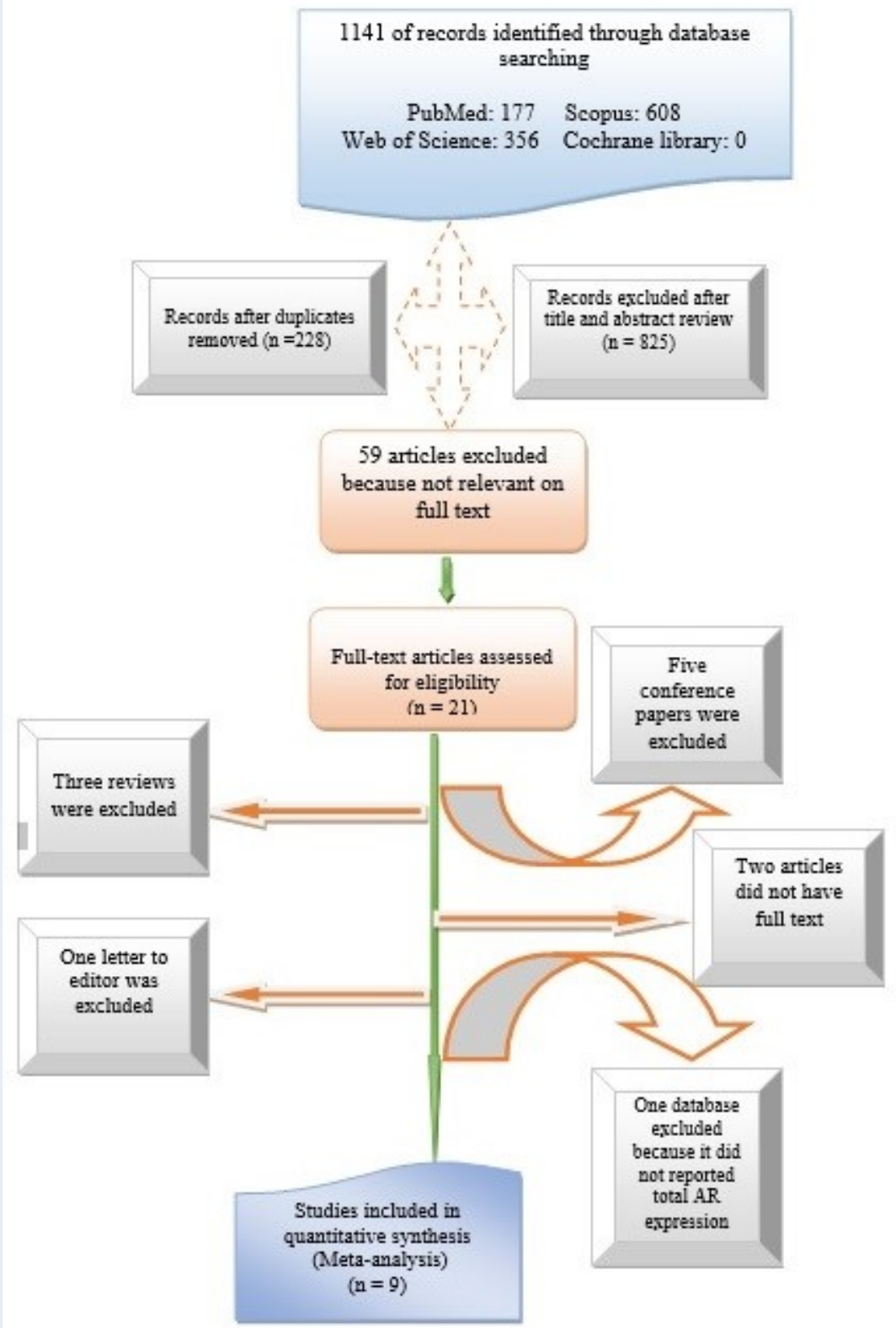

Figure 1: Flow chart of studies reviewed and included in the present meta-analysis.

\section{CONCLUSION}

As our knowledge, this study is first meta-analysis to research the impact of AR expression on RCC patients. The current study showed the level of expression of $\mathrm{AR}$ and its relative with tumor grade and $\mathrm{pT}$ stage in RCC patients. Additional studies are needed to the role of $\mathrm{AR}$ expression in these patients.

\section{COMPETING INTERESTS}

The author(s) declared no conflicts of interest.

\section{AUTHORS' CONTRIBUTIONS}

Conceptualization: ES MP

Formal analysis: ES

Methodology: ES HA

Project administration: ES MP HA HM

Software: ES

Validation: HM HA

Writing - original draft: ES

Writing - review \& editing: ES MP HA HM 


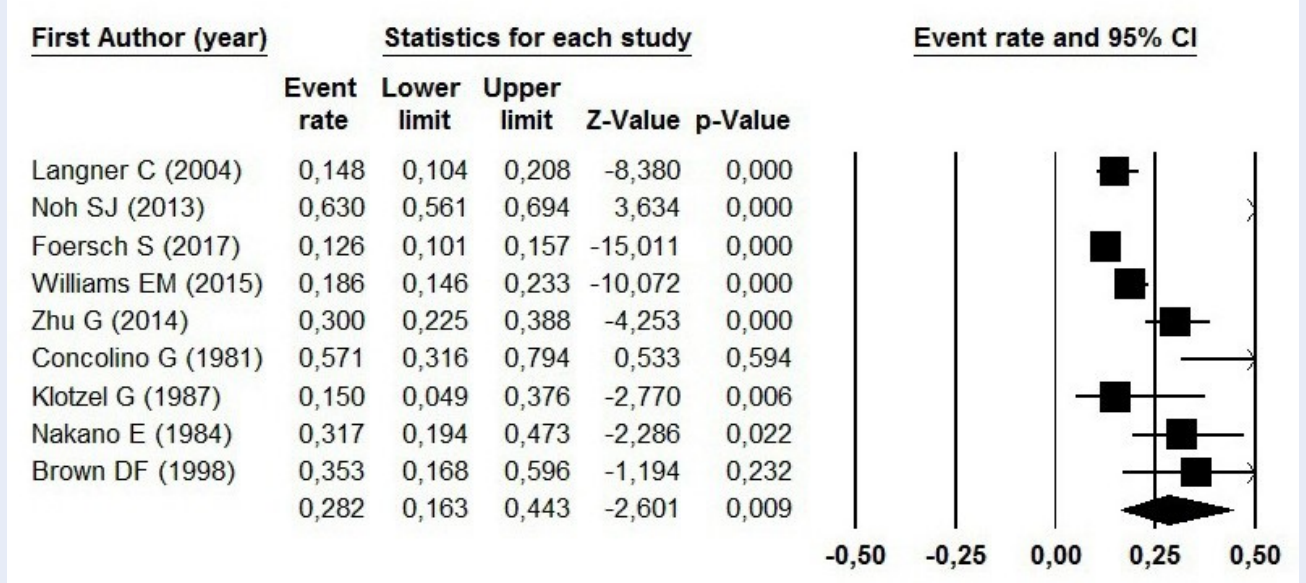

Figure 2: Forest plot of OR for expression in RCC patients. Horizontal line represents $95 \% \mathrm{Cl}$ of each study. The diamond indicates the pooled OR value. OR: odds ratio; $\mathbf{C l}$ : confidence interval.

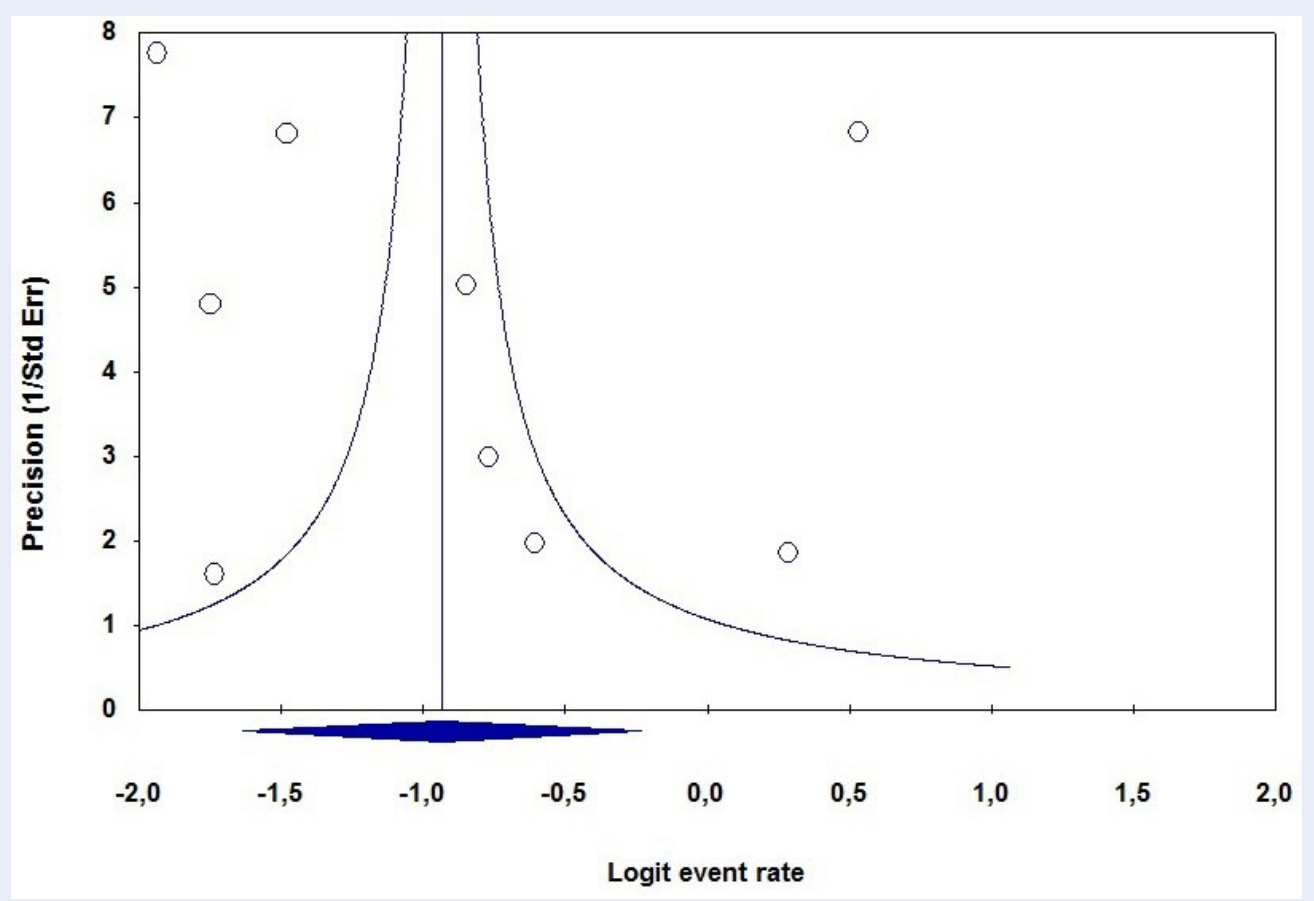

Figure 3: Funnel plot for potential publication bias of expression of RCC. 


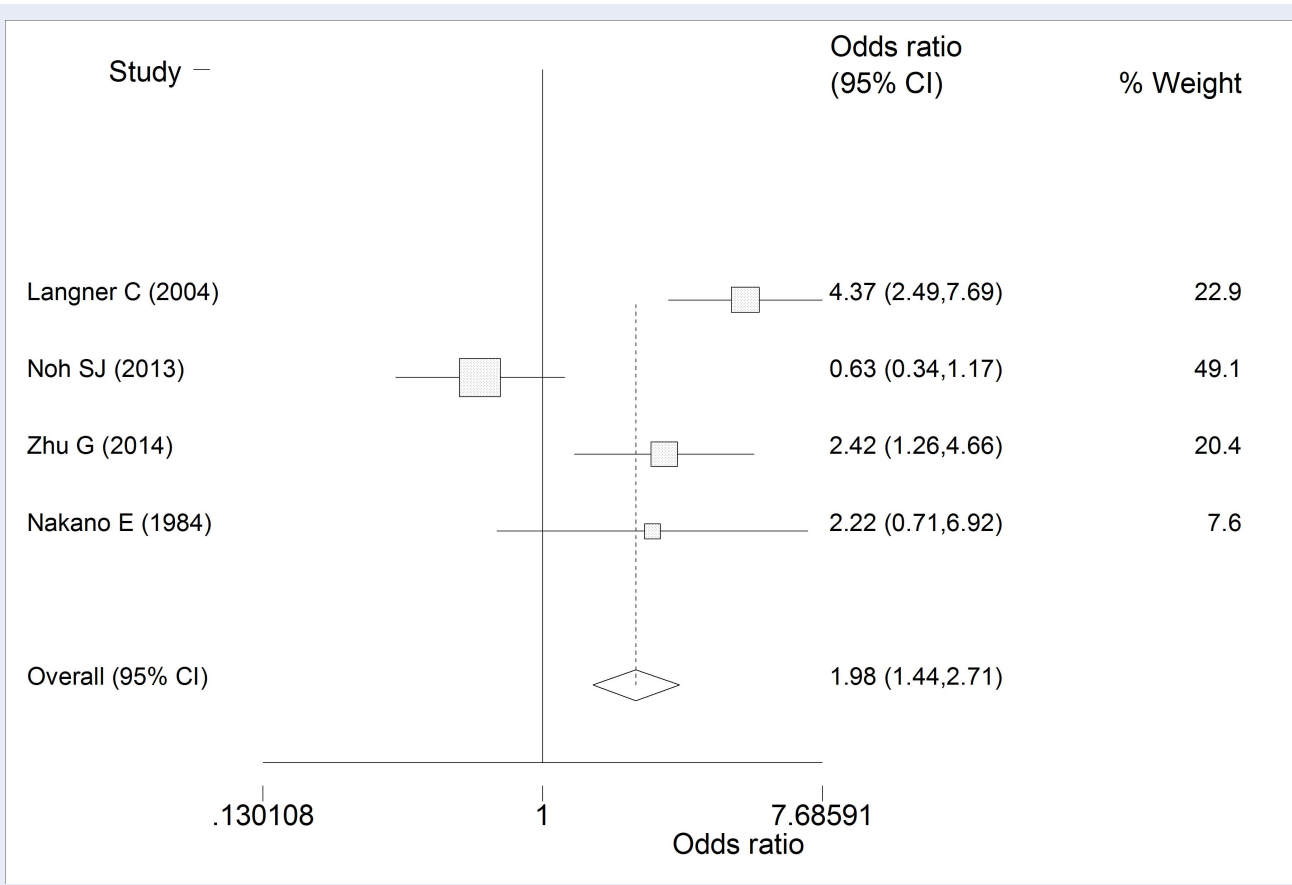

Figure 4: Forest plot of OR for tumor grade. Horizontal line represents $95 \% \mathrm{Cl}$ of each study. The diamond indicates the pooled $\mathrm{OR}$ value. OR: odds ratio; $\mathbf{C l}$ : confidence interval.

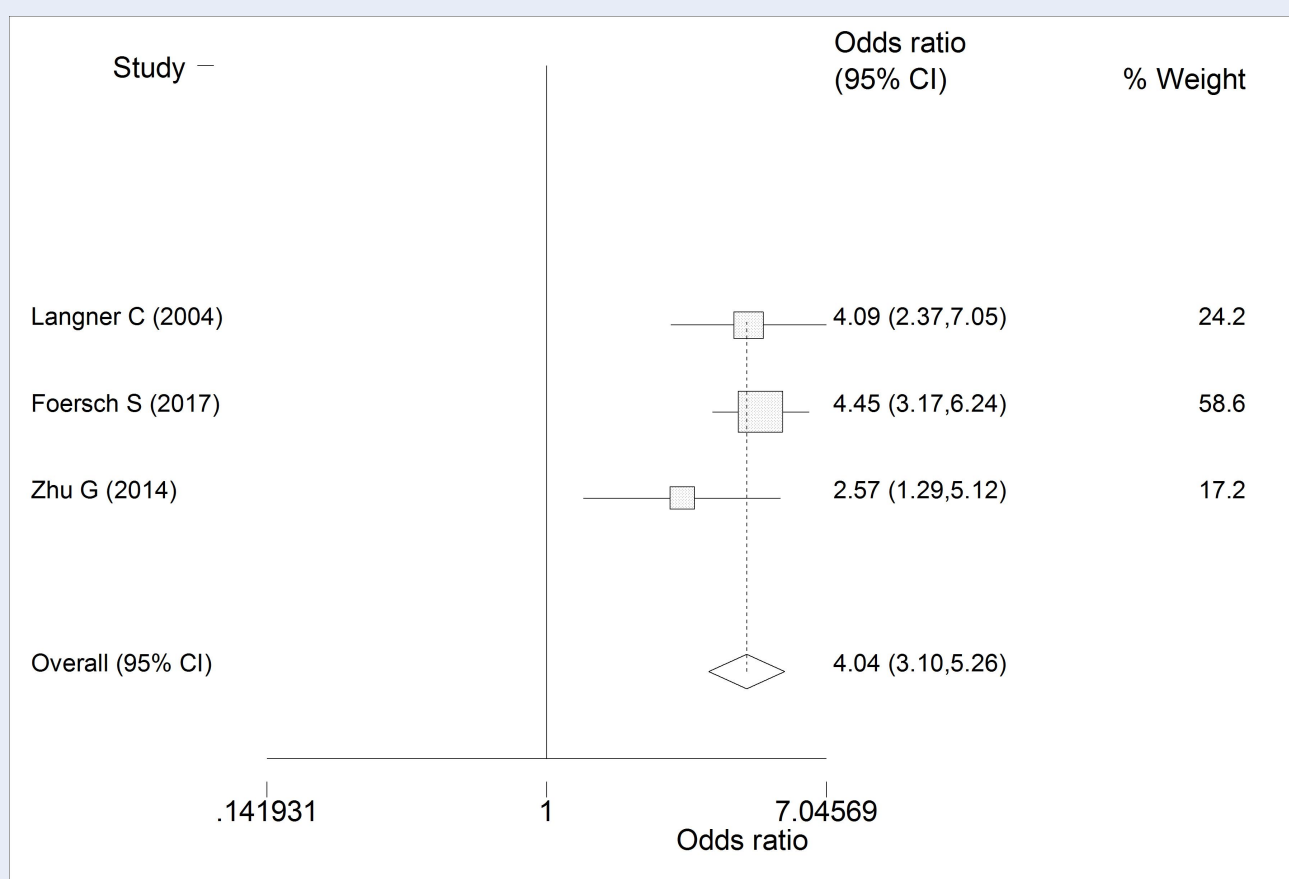

Figure 5: Forest plot of OR for pT stage. Horizontal line represents $95 \% \mathrm{Cl}$ of each study. The diamond indicates the pooled OR value. OR: odds ratio; Cl: confidence interval. 


\begin{tabular}{|c|c|c|c|c|c|c|c|c|c|c|}
\hline \multirow{2}{*}{ First Author (year) } & \multirow{2}{*}{ Nation } & \multirow{2}{*}{ Patient } & \multirow{2}{*}{$\begin{array}{c}\text { Total } \\
\text { androgen } \\
\text { expression }\end{array}$} & \multicolumn{2}{|c|}{ Sex } & \multicolumn{2}{|c|}{ pT Stage } & \multicolumn{2}{|c|}{ Grade } & \multirow{2}{*}{$\begin{array}{l}\text { Age Mean } \\
\text { (Min-Max) }\end{array}$} \\
\hline & & & & Male & Femal & e Low & High & Low & High & \\
\hline Langner C, $2004^{9}$ & Austria & 182 & 27 & 24 & 3 & $102(24$ & 4) $80(3)$ & $99(21)$ & $83(6)$ & - \\
\hline Noh SJ, $2013^{10}$ & Korea & 200 & 126 & 93 & 33 & - & - & $158(101$ & $42(25)$ & $58.13(29-82)$ \\
\hline Foersch S, $2017^{14}$ & German! & ly 546 & 69 & - & - & $348(64) 1$ & 198(36) & $463(\mathrm{NA})$ & ) $83(\mathrm{NA})$ & - \\
\hline Williams EM, $2015^{15}$ & USA & 307 & 57 & - & - & - & - & - & - & - \\
\hline Zhu G, $2014^{11}$ & China & 120 & 36 & 24 & 12 & $95(34)$ & $25(2)$ & $89(32)$ & $31(4)$ & $63(35-82)$ \\
\hline Concolino G, $1981^{16}$ & Italy & 14 & 8 & - & - & - & - & - & - & - \\
\hline Klotzl G, $1987^{17}$ & Germany & 20 & 3 & - & - & - & - & - & - & - \\
\hline Nakano E, $1984^{18}$ & Japan & 41 & 13 & 30 & 11 & - & - & $20(6)$ & $21(7)$ & $-(46-76)$ \\
\hline Brown DF, $1998^{19}$ & USA & 17 & 6 & - & - & - & - & - & - & - \\
\hline
\end{tabular}

\section{ABBREVIATIONS}

AR: Androgen Receptor

ccRCC: Clear Cell Renal Cell Carcinoma

CI: Confidence Interval

ER: Estrogen Receptor

pT Stage: Pathologic Tumor Stage

PR: Progesterone Receptor

RCC: Renal Cell Carcinoma

\section{REFERENCES}

1. Payandeh M, Sadeghi E, Sadeghi M. Two Side Effects of Sutent Therapy in Renal Cell Carcinoma: A Case Report. 2017;10:e4040. Available from: DOI:10.5812/ijcm.4040.

2. Eble JL, Sauter G, Epstein J, Sesterhenn I. Pathology and Genetics of Tumours of the Urinary System and Male Genital Organs: WHO Classification of Tumours; 2004.

3. Brinkmann AO, Faber PW, van Rooij HC, Kuiper GG, Ris C, Klaassen $P$. The human androgen receptor: domain structure, genomic organization and regulation of expression. Journal of Steroid Biochemistry. 1989;34:307-10. Available from: Doi:10.1016/0022-4731(89)90098-8.

4. Kimura N, Mizokami A, Oonuma T, Sasano H, Nagura $\mathrm{H}$. Immunocytochemical localization of androgen receptor with polyclonal antibody in paraffin-embedded human tissues. The Journal of Histochemistry and Cytochemistry. 1993:41:671-8. Available from: Doi:10.1177/41.5.8468448.

5. Nam JK, Park SW, Lee SD, Chung MK. Prognostic value of sexhormone receptor expression in non-muscle-invasive bladder cancer. Yonsei Medical Journal. 2014;55:1214-21. Available from: DOI:10.3349/ymj.2014.55.5.1214.

6. Nodin B, Zendehrokh N, Brandstedt J, Nilsson E, Manjer J, Brennan DJ. Increased androgen receptor expression in serous carcinoma of the ovary is associated with an improved survival. Journal of Ovarian Research. 2010;3:14. Available from: Doi:10.1186/1757-2215-3-14.

7. Rades D, Seibold ND, Schild SE, Bruchhage KL, Gebhard MP, Noack F. Androgen receptor expression: prognostic value in locally advanced squamous cell carcinoma of the head and neck. Strahlentherapie und Onkologie. 2013;189:849-55. Available from: DOI:10.1007/s00066-013-0389-z.

8. Vera-Badillo FE, Templeton AJ, de Gouveia P, Diaz-Padilla I, Bedard PL, Al-Mubarak M. Androgen receptor expression and outcomes in early breast cancer: a systematic review and meta-analysis. Journal of the National Cancer Institute. 2014;106:djt319. Available from: DOI:10.1093/jnci/djt319.

9. Langner C, Ratschek M, Rehak P, Schips L, Zigeuner R. Steroid hormone receptor expression in renal cell carcinoma: an immunohistochemical analysis of 182 tumors. The Journal of Urology. 2004;171:611-4. Available from: DOI:10.1097/01.ju. 0000108040.14303.c2.

10. Noh SJ, Kang MJ, Kim KM, Bae JS, Park HS, Moon WS. Acetylation status of P53 and the expression of DBC1, SIRT1, and androgen receptor are associated with survival in clear cell renal cell carcinoma patients. Pathology. 2013;45:574-80. Available from: DOI:10.1097/PAT.0b013e3283652c7a.

11. Zhu G, Liang L, Li L, Dang Q, Song W, Yeh S. The expression and evaluation of androgen receptor in human renal cell carcinoma. Urology. 2014;83:510.e19-24. Available from: DOI:10.1016/j.urology.2013.10.022.

12. $M$ MW, B BJ, B BJ. Tumors of the Kidney, Bladder, and Related Urinary Structures. In: Atlas of Tumor Pathology. vol. 11. Washington, D. C.: Armed Forces Institute of Pathology; 1994. p. 92132.

13. Nolan LP, Heatley MK. The value of immunocytochemistry in distinguishing between clear cell carcinoma of the kidney and ovary. International Journal of Gynecological Pathology. 2001;20:155-9. Available from: Doi:10.1097/00004347200104000-00007.

14. Foersch S, Schindeldecker M, Keith M, Tagscherer KE, Fernandez A, Stenzel PJ. Prognostic relevance of androgen receptor expression in renal cell carcinomas. Oncotarget. 2017;8:78545-55. Available from: DOI:10.18632/oncotarget. 20827.

15. Williams EM, Higgins JP, Sangoi AR, McKenney JK, Troxell $\mathrm{ML}$. Androgen receptor immunohistochemistry in genitourinary neoplasms. International Urology and Nephrology. 2015;47:81-5. Available from: DOI:10.1007/s11255-014-0834-

16. Concolino G, Marocchi A, Toscano V, Silverio FD. Nuclear androgen receptor as marker of responsiveness to medroxyprogesterone acetate in human renal cell carcinoma. Journal of Steroid Biochemistry. 1981;15:397-402. Available from: Doi:10.1016/0022-4731(81)90304-6.

17. Klotzl G, Otto $\mathrm{U}$, Becker $\mathrm{H}$, Klosterhalfen $\mathrm{H}$. Determination of androgen, progestin and estrogen receptors with two different assays in renal cell carcinoma. Urologia Internationalis. 1987:42:100-4. Available from: Doi:10.1159/000281864.

18. Nakano E, Tada Y, Fujioka H, Matsuda M, Osafune M, Kotake $\mathrm{T}$. Hormone receptor in renal cell carcinoma and correlation with clinical response to endocrine therapy. The Journal of 
Urology. 1984;132:240-5. Available from: Doi:10.1016/s00225347(17)49577-2.

19. Brown DF, Dababo MA, Hladik CL, Eagan KP, White CL, Rushing EJ. Hormone receptor immunoreactivity in hemangioblastomas and clear cell renal cell carcinomas. Modern Pathology. 1998;11:55-9.

20. Elattar A, Warburton KG, Mukhopadhyay A, Freer RM, Shaheen $\mathrm{F}$, Cross $\mathrm{P}$. Androgen receptor expression is a biological marker for androgen sensitivity in high grade serous epithelial ovarian cancer. Gynecologic Oncology. 2012;124:142-7. Available from: DOI:10.1016/j.ygyno.2011.09.004.

21. Shyr CR, Chen CC, Hsieh TF, Chang CH, Ma WL, Yeh S. The expression and actions of androgen receptor in upper urinary tract urothelial carcinoma (UUTUC) tissues and the primary cultured cells. Endocrine. 2013;43:191-9. Available from: DOI:10.1007/s12020-012-9762-4.

22. Rini BI, Atkins MB. Resistance to targeted therapy in renal-cell carcinoma. The Lancet Oncology. 2009;10:992-1000. Available from: Doi:10.1016/s1470-2045(09)70240-2.

23. Paine $\mathrm{CH}$, Wright FW, Ellis $\mathrm{F}$. The use of progestogen in the treatment of metastatic carcinoma of the kidney and uterine body. British Journal of Cancer. 1970;24:277-82. Available from: DOI:10.1038/bjc.1970.31.

24. Wagle DG, Murphy GP. Hormonal therapy in advanced renal cell carcinoma. Cancer. 1971;28:318-21. Available from: Doi:10.1002/1097-0142(197108)28:2<318:: aid-cncr2820280209>3.0.co;2-d.

25. Niemeier LA, Dabbs DJ, Beriwal S, Striebel JM, Bhargava R. Androgen receptor in breast cancer: expression in estrogen receptor-positive tumors and in estrogen receptor-negative tumors with apocrine differentiation. Modern Pathology. 2010;23:205-12. Available from: DOI:10.1038/modpathol. 2009.159.

26. Barton VN, DÁmato NC, Gordon MA, Lind HT, Spoelstra NS, Babbs BL. Multiple molecular subtypes of triple-negative breast cancer critically rely on androgen receptor and respond to enzalutamide in vivo. Molecular Cancer Therapeutics. 2015;14:769-78. Available from: Doi:10.1158/1535-7163.mct14-0926.

27. Sasaki M, Nomoto $M$, Yonezawa $S$, Nakagawa $M$, Sakuragi $\mathrm{N}$, Fujimoto $\mathrm{S}$. Distribution of a single nucleotide polymor- phism on codon 211 of the androgen receptor gene and its correlation with human renal cell cancer in Japanese patients. Biochemical and Biophysical Research Communications. 2004;321:468-71. Available from: DOI:10.1016/j.bbrc. 2004.06.163.

28. Zhao H, Leppert JT, Peehl DM. A Protective Role for Androgen Receptor in Clear Cell Renal Cell Carcinoma Based on Mining TCGA Data. PLoS One. 2016;11:e0146505. Available from: DOI:10.1371/journal.pone.0146505.

29. Kominea A, Konstantinopoulos PA, Kapranos N, Vandoros $G$ Gkermpesi M, Andricopoulos P. Androgen receptor (AR) expression is an independent unfavorable prognostic factor in gastric cancer. Journal of Cancer Research and Clinical Oncology. 2004;130:253-8. Available from: DOI:10.1007/s00432003-0531-x.

30. Segawa N, Mori I, Utsunomiya H, Nakamura M, Nakamura Y, Shan L. Prognostic significance of neuroendocrine differentiation, proliferation activity and androgen receptor expression in prostate cancer. Pathology International. 2001;51:452-9. Available from: DOI:10.1046/j.1440-1827.2001.01226.x.

31. Mir C, Shariat SF, van der Kwast TH, Ashfaq R, Lotan Y, Evans A. Loss of androgen receptor expression is not associated with pathological stage, grade, gender or outcome in bladder cancer: a large multi-institutional study. BJU International. 2011;108:24-30. Available from: DOI:10.1111/j.1464-410X. 2010.09834.x.

32. Boorjian S, Ugras S, Mongan NP, Gudas LJ, You X, Tickoo SK. Androgen receptor expression is inversely correlated with pathologic tumor stage in bladder cancer. Urology. 2004;64:383-8. Available from: DOI:10.1016/j.urology.2004. 03.025 .

33. Tuygun C, Kankaya D, Imamoglu A, Sertcelik A, Zengin K, Oktay M. Sex-specific hormone receptors in urothelial carcinomas of the human urinary bladder: a comparative analysis of clinicopathological features and survival outcomes according to receptor expression. Urologic Oncology. 2011;29:43-51. Available from: DOI:10.1016/j.urolonc.2009.01.033.

34. Mejean A, Oudard S, Thiounn N. Prognostic factors of renal cell carcinoma. The Journal of Urology. 2003;169:821-7. Available from: DOI:10.1097/01.ju.0000051378.14270.2a. 